(c) American Dairy Science Association, 2006.

\title{
Developmental and Nutritional Regulation of the Prepubertal Bovine Mammary Gland: II. Epithelial Cell Proliferation, Parenchymal Accretion Rate, and Allometric Growth
}

\author{
M. J. Meyer, ${ }^{\star 1}$ A. V. Capuco,† D. A. Ross, ${ }^{\star}$ L. M. Lintault, ${ }^{\star}$ and M. E. Van Amburgh ${ }^{\star 2}$ \\ *Department of Animal Science, Cornell University, Ithaca, NY 14850 \\ †Bovine Functional Genomics Lab, USDA-ARS, Beltsville, MD 20705
}

\section{ABSTRACT}

It is well documented that elevated nutrient intake prior to puberty reduces prepubertal mammary development in the bovine. The companion paper demonstrated that age at harvest is a primary determinant of parenchymal (PAR) mass and that any effects of elevated energy intake on mechanisms regulating mammary development are dwarfed by this effect of time. Therefore, it is hypothesized that while causing a decrease in prepubertal PAR mass, elevated nutrient intake will have no effect on growth characteristics of the mammary gland. The objectives of this experiment were to evaluate the effects of increased nutrient intake from early in life on 1) mammary epithelial cell proliferation, 2) mammary PAR DNA accretion rates, and 3) the dynamics of prepubertal allometric PAR growth. Holstein heifers $(\mathrm{n}=78$ ) were fed from $45 \mathrm{~kg}$ of body weight either elevated $(\mathrm{E})$ or restricted $(\mathrm{R})$ levels of nutrients to support 950 (E) or 650 (R) g/d of body weight gain. Six heifers per treatment were harvested at $50-\mathrm{kg}$ increments from 100 to $350 \mathrm{~kg}$ of body weight. Heifers on the $\mathrm{E}$ plane of nutrition had higher plasma leptin and less PAR DNA than their body weightmatched R-intake cohorts. Despite this reduction in PAR DNA, treatment did not negatively influence mammary epithelial cell proliferation or the PAR DNA accretion rate. Dynamics of allometric and isometric mammary growth were also unaffected by the level of nutrient intake, as was exit from allometric growth. This work represents the first demonstrating that the level of nutrient intake and the concomitant increase in plasma leptin have no measurable influence on 1 ) the rate of PAR DNA accretion, 2) mammary epithelial cell proliferation, or 3) total PAR mass and, by default, the local or systemic controls that coordinate these processes.

\footnotetext{
Received October 7, 2005.

Accepted July 17, 2006.

${ }^{1}$ Current address: Mammary Biology and Tumorigenesis Laboratory, National Cancer Institute, National Institutes of Health, Building 37, Room 1108, 37 Convent Drive, Bethesda, MD 20892-4254.

${ }^{2}$ Corresponding author: mev1@cornell.edu
}

Key words: heifer, mammary development, allometric growth

\section{INTRODUCTION}

In the bovine, postnatal mammary growth occurs at an allometric rate prior to puberty and returns to an isometric rate after puberty (Sinha and Tucker, 1969). It is well documented that elevated nutrient intake during this allometric growth phase results in reduced parenchymal (PAR) mass and DNA (Sejrsen et al., 1982; Petitclerc et al., 1984; Capuco et al., 1995). Several hypotheses have been proposed to explain this phenomenon. Elevated nutrient intake affects plasma concentrations of a host of homeorhetic signals, including growth hormone (Sejrsen et al., 1983) and leptin (Block et al., 2003). Both hormones have been proposed as mediators of diet-impaired prepubertal mammary development. Growth hormone is required for prepubertal mammary development (Cowie et al., 1966) and systemic levels are reduced in animals on high nutrient intakes (Sejrsen et al., 1983). Plasma leptin is increased with elevated nutrient intake (Block et al., 2003), and intramammary leptin infusions have blocked epithelial cell proliferation in the prepubertal bovine mammary gland (Silva et al., 2003). These observations have led to the hypotheses that elevated nutrient intake reduces prepubertal mammary development by impairing epithelial cell proliferation because of reduced circulating growth hormone (Sejrsen, 1978; Sejrsen et al., 1999) or elevated circulating levels of leptin (Silva et al., 2002).

In a companion paper (Meyer et al., 2006), we suggested that elevated energy intake does not directly impair mammary growth. Instead, the difference in age at harvest, which is often an artifact of growing heifers at divergent rates of BW gain, is the primary cause for the observed differences in PAR mass. Therefore, we hypothesized that while experiencing decreased PAR mass at harvest, prepubertal heifers raised on an elevated plane of nutrition would have mammary epithelial cell proliferation, PAR DNA accretion rates, and dynamics of prepubertal allometric mammary growth similar to those of their intake-restricted cohorts. Ef- 
fects on PAR and fat pad mass, DNA, and composition are described in a companion paper (Meyer et al., 2006).

\section{MATERIALS AND METHODS}

\section{Animals and Tissue Collection}

The Cornell University Animal Care and Use Committee approved all procedures used in this study. The experimental design is described in detail in the companion paper (Meyer et al., 2006). Briefly, 78 Holstein heifers (44.2 kg of BW, $9.9 \mathrm{~d}$ of age) were assigned to an elevated $(\mathbf{E})$ or restricted $(\mathbf{R})$ level of nutrient intake supporting 950 or $650 \mathrm{~g}$ of daily BW gain.

Prior to weaning, all heifers were fed twice daily at 0630 and $1800 \mathrm{~h}$. E-heifers received a diet with $29 \% \mathrm{CP}$ and $19 \%$ fat milk replacer at $0.32 \mathrm{Mcal}$ intake energy $/ \mathrm{kg}$ of $\mathrm{BW}^{0.75}$, whereas R-heifers received a diet with $22 \%$ $\mathrm{CP}$ and $21 \%$ fat milk replacer at $0.20 \mathrm{Mcal}$ intake energy/kg of $\mathrm{BW}^{0.75}$. Weaning was initiated after approximately 6 wk on the treatment. A textured starter was offered from wk 3 of the study through wk 10 of the study, after which heifers were fed a TMR until the end of the treatment period. Heifers were weighed weekly and the amount of milk replacer or TMR offered was adjusted to meet the targeted rate of BW gain. Composition of the milk replacer, starter, and TMR were described previously (Meyer et al., 2006).

Once heifers reached $225 \mathrm{~kg}$ of BW, blood was collected twice weekly via jugular venipuncture and the plasma progesterone concentration was determined (Coat-A-Count progesterone radio immunoassay; Diagnostic Products Corp., Los Angeles, CA). Plasma progesterone concentrations greater than $1 \mathrm{ng} / \mathrm{mL}$ were interpreted to mean that the heifer possessed a functional corpus luteum and was therefore pubertal.

Six heifers were harvested at approximately $45 \mathrm{~kg}$ of BW to determine mammary development prior to initiation of the treatment. The remaining heifers (6 per treatment per harvest weight) were harvested at the following live BW: $100,150,200,250,300$, or 350 $\mathrm{kg}$. Harvest was conducted at the Cornell University abattoir by stunning with a captive bolt followed by exsanguination. Pubertal heifers were harvested in the luteal phase of the estrous cycle to minimize variation in PAR DNA associated with estrus (Sinha and Tucker, 1969). One to $2 \mathrm{~h}$ prior to harvest, each heifer was intravenously injected with 5-bromo-2-deoxyuridine (BrdU; $20 \mathrm{mg} / \mathrm{mL}$ in $\mathrm{pH} 8.5$ saline) at a dose of $5 \mathrm{mg} /$ $\mathrm{kg}$ of BW (Capuco et al., 2002). At harvest, the udder was removed and weighed. The left half was immediately dissected and tissue samples from the mid-PAR region were collected, fixed overnight in $10 \%$ neutral buffered formalin at $4^{\circ} \mathrm{C}$, and stored in $70 \%$ ethanol until further processing for immunohistochemistry.
Following collection of PAR tissue from the left half, the udder was skinned and separated into right and left halves at the medial suspensory ligament. The skin and teats were weighed together and the skinned right half was weighed separately. The weight of the skinned left half was determined by the difference.

The skinned right half was frozen on dry ice and stored at $-20^{\circ} \mathrm{C}$ until further processing. At a later date, the right half was partially thawed at $4^{\circ} \mathrm{C}$ and cut into 5 -mm-thick slices using a meat slicer. From these slices, the PAR was quantitatively dissected by color, collected, and weighed. Total dissected PAR from each right udder-half was ground using a bowl chopper and subsampled. These PAR subsamples were frozen in liquid nitrogen and further ground to a fine powder in a commercial blender. The PAR DNA content was determined with these powered samples using the fluorometric bisbenzimidazole technique (Labarca and Paigen, 1980) as described in the companion paper (Meyer et al., 2006).

\section{Plasma Leptin Assay}

The plasma leptin concentration was determined in individual samples collected weekly for the final $4 \mathrm{wk}$ before harvest. The leptin concentration was assayed in duplicate by a double antibody bovine radioimmunoassay (Ehrhardt et al., 2000).

\section{Calculation of Daily PAR DNA Accretion Rates}

To determine the daily PAR DNA accretion rates between harvest weights, the difference in the PAR DNA content between consecutive harvest weights was divided by the difference in age between the harvest weights. For example, when calculating the rate between 150 and $200 \mathrm{~kg}$ of BW, the difference in treatment mean PAR DNA content at $150 \mathrm{~kg}$ of BW and each heifer's individual PAR DNA content at $200 \mathrm{~kg}$ of BW was first determined, giving each $200-\mathrm{kg}$ heifer a $\triangle \mathrm{PAR}$ DNA value. The amount of time between these 2 harvest weights was then calculated for each $200-\mathrm{kg}$ heifer ( $\Delta$ age) by taking the treatment mean age at $150 \mathrm{~kg}$ of BW minus each individual heifer's age at $200 \mathrm{~kg}$ of BW. The PAR DNA accretion rate was then calculated by dividing $\triangle$ PAR DNA by $\Delta$ age. To ensure that using the mean ages of heifers per treatment weight did not bias the evaluation, the actual age of each heifer was also used to calculate the PAR DNA accretion rate for each treatment. Statistically, the results were similar; thus, only the mean age differences are reported.

\section{Immunohistochemistry}

After fixation, tissues were processed for immunohistochemistry as described previously (Capuco et al., 
2002). Tissue sections were photographed with a Spot digital camera (Diagnostic Instruments Inc., Sterling Heights, MI) on a Zeiss Axioscope microscope (Carl Zeiss Inc., Thornwood, NY).

To quantify the fraction of BrdU-labeled epithelial cells, photographs of tissue sections processed for immunological detection of labeled cells were captured as digital images and saved on a computer. Ten microscopic fields were photographed and epithelial cells in these fields were evaluated. On average, 5,000 epithelial cells were evaluated per heifer. The total number of BrdU-labeled epithelial cells per field was divided by the total number of epithelial cells per field. For each heifer, the average of all fields, which represented the BrdU-labeling or proliferation index, was then determined.

\section{Statistical Analysis}

Data were analyzed by the MIXED procedure of SAS (SAS Institute, 2000). With the exception of the PAR DNA accretion rate, sums of squares were partitioned to treatment, harvest weight, and treatment $\times$ harvest weight interaction. Calf was the experimental unit. For the PAR DNA accretion rate, sums of squares were partitioned to treatment, BW interval (i.e., $45 \rightarrow 100$ $\mathrm{kg}, 100 \rightarrow 150 \mathrm{~kg}$, etc.), and the interaction of these 2 main effects. To facilitate interpretation of the data, the PDIFF option of SAS was used to calculate means of the main effects (treatment and harvest weight) as well as the means of their interaction and significance. Comparisons of regressions were conducted using the approach of Neter et al. (1990) in which residuals were tested for equal variances and slopes were tested for uniformity. In all cases, when comparing means, an overall level of statistical significance was established at $P<0.05$.

\section{RESULTS}

\section{Body Growth, Mammary Development, and Plasma Leptin}

As previously reported, the lifetime average daily gain for E- and R-heifers was 930 and $660 \mathrm{~g} / \mathrm{d}$, respectively $(P<0.01$; Meyer et al., 2006). As a result of divergent rates of BW gain, E-heifers were younger at harvest at a common $\mathrm{BW}$ and younger at puberty than R-heifers $(P<0.01)$. Concomitant with the increased rate of BW gain, E-heifers had greater plasma leptin than R-heifers (Table 1). Additionally, E-heifers had less PAR mass and PAR DNA at common BW than did R-heifers $(P<0.01)$.
Table 1. Treatment effects on plasma leptin

\begin{tabular}{llllll}
\hline & & & & \multicolumn{3}{c}{ Significance level } \\
\cline { 4 - 6 } $\begin{array}{l}\text { Plane of } \\
\text { nutrition }\end{array}$ & $\begin{array}{l}\text { Leptin, } \\
\text { ng/mL }\end{array}$ & SEM & TRT $^{1}$ & BW & TRT $\times$ BW \\
\hline Restricted & 1.99 & 0.050 & $<0.01$ & $<0.01$ & $\mathrm{NS}^{2}$ \\
Elevated & 2.26 & 0.098 & & & \\
\hline
\end{tabular}

${ }^{1}$ TRT $=$ Effect of the plane of nutrition.

${ }^{2}$ Nonsignificant.

\section{Epithelial Cell Proliferation}

There was a tendency for elevated nutrient intake to increase mammary epithelial cell proliferation $(P=$ 0.08 ), as assessed by the BrdU-labeling index, however, this was largely due to an interaction between treatment and harvest weight ( $P=0.16$, Figure 1). Specifically, at the $100-\mathrm{kg}$ harvest weight, $8.9 \%$ of E-heifers' mammary epithelial cells incorporated BrdU, whereas only $4.9 \%$ of R-heifers' mammary epithelial cells incorporated the thymidine analog. This difference was lost by $150 \mathrm{~kg}$ of BW. Body weight at harvest significantly influenced BrdU incorporation, as epithelial cell proliferation decreased with increasing harvest weight $(P$ $<0.01)$.

\section{PAR DNA Accretion Rate}

As illustrated in Figure 2, the level of nutrient intake had no effect on PAR DNA accretion rates $(P=0.63)$. The accretion rate was, however, affected by BW $(P<$ 0.01 ). Irrespective of treatment, the PAR accretion rate increased gradually between 45 and $150 \mathrm{~kg}$ of BW, pla-

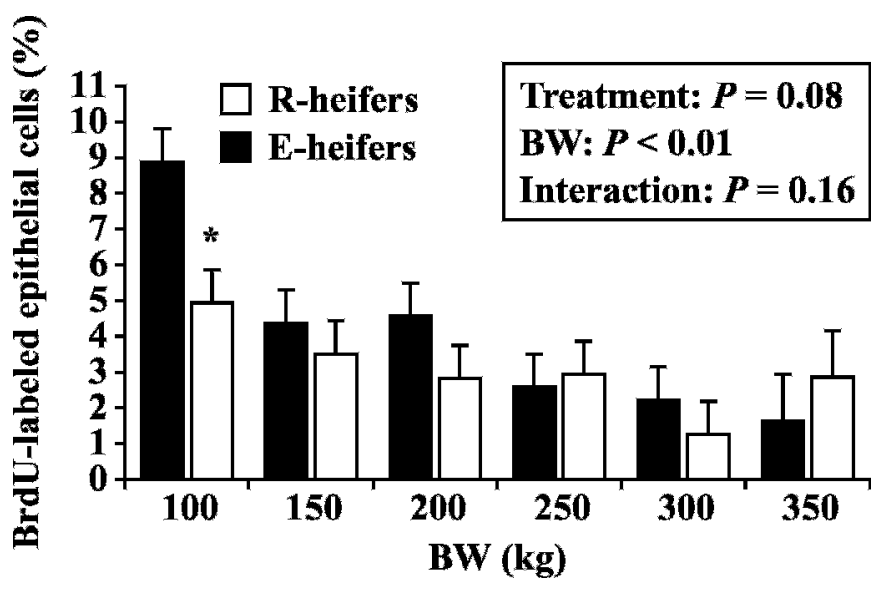

Figure 1. Least squares means $( \pm \mathrm{SEM})$ of the percentage of mammary epithelial cells labeling positive for 5-bromo-2-deoxyuridine (BrdU) among prepubertal heifers across 6 BW raised on an elevated (E; solid bars) or restricted (R; open bars) plane of nutrition. Within body weight, an asterisk $(*)$ indicates a plane of nutrition effect $(P$ $<0.05)$ at the specific harvest weight. 


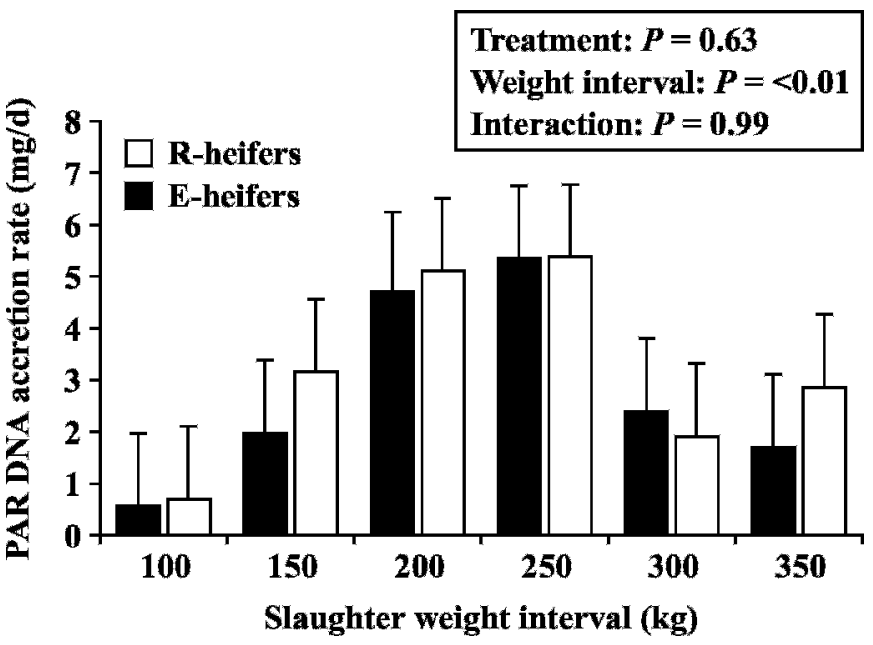

Figure 2. Least squares means $( \pm$ SEM) of parenchymal (PAR) DNA accretion rates between harvest weights among prepubertal heifers raised on an elevated (E; solid bars) or restricted (R; open bars) plane of nutrition.

teaued between 150 and $250 \mathrm{~kg}$ of $\mathrm{BW}$, then decreased by $50 \%$ where it remained until $350 \mathrm{~kg}$.

\section{Treatment Effects on Allometric Mammary Growth}

To evaluate the effect of treatment on timing into and out of prepubertal allometric mammary growth, the $\log _{10}$ of PAR DNA was plotted against the $\log _{10}$ of BW at harvest (Figure 3). Slopes of the allometric growth curve slopes were 3.29 and 3.11 for E- and Rheifers, respectively. Isometric growth curves were 1.28 and 1.44 for E- and R-heifers, respectively. Treatment had no effect on the slope of either allometric $(P=0.66)$ or isometric $(P=0.75)$ growth curves. Furthermore, both treatment groups exited allometric growth between 250 and $300 \mathrm{~kg}$ of BW. This BW range also encompassed the average BW at puberty $(280 \mathrm{~kg})$, which is indicated by the arrow in Figure 3. In this figure, heifers harvested prior to puberty are represented by an open circle (E-heifers) or dash (R-heifers). Heifers that reached puberty before harvest, and were therefore postpubertal at harvest, are represented by an $\times(\mathrm{E}-$ heifers) or open triangle (R-heifers).

To further evaluate the possible relationship between the peripubescent period (defined as the time in which a heifer's BW is approximately $50 \mathrm{~kg}$ on either side of the average BW at puberty) and exit from prepubertal allometric growth, the $\log _{10}$ PAR DNA was plotted against the $\log _{10}$ weeks of age at harvest (Figure 4, Eand R-heifers in the top and bottom panels, respectively). As described in the companion paper (Meyer et al., 2006), age at puberty was significantly reduced in E-heifers, whereas BW at puberty was unaffected. In

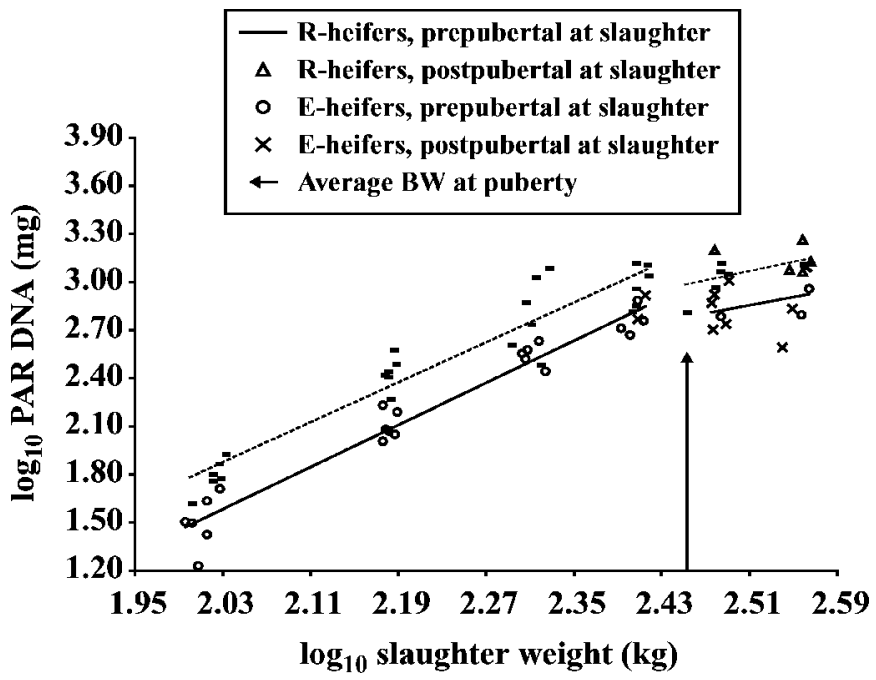

Figure 3. Prepubertal mammary parenchymal (PAR) development in heifers raised on an elevated (E) or restricted (R) plane of nutrition and harvested at $6 \mathrm{BW}$ between birth and $350 \mathrm{~kg}$. Heifers that did not reach puberty before harvest are marked differently from those that were postpubertal at harvest. R-heifers harvested before reaching puberty are represented by a dash (-), whereas those that were postpubertal at harvest are represented by an open triangle $(\triangle)$. E-heifers harvested before reaching puberty are represented by an open circle $(O)$, whereas those that were postpubertal at harvest are represented by an $\times$. The average BW at puberty for all heifers is also indicated (arrow). Data are presented as $\log _{10} \mathrm{BW}$ at harvest vs. $\log _{10}$ PAR DNA at harvest. Within treatment, data are grouped into the allometric and isometric phase of prepubertal mammary development. Within the allometric phase, regression for the heifers with an $\mathrm{R}$ plane of nutrition (dashed line) is $y=3.113 x-4.4425, \mathrm{R}^{2}=$ $90.7 \%$, and regression for those with the E plane of nutrition (heavy line) is $y=3.2852 x-5.086, \mathrm{R}^{2}=96.0 \%$. The slopes of these 2 curves are similar $(P=0.66)$. Within the isometric phase, regression for heifers with the $\mathrm{R}$ plane of nutrition is $y=1.4425 x-0.5519, \mathrm{R}^{2}=$ $30.0 \%$, and regression for those with the $\mathrm{E}$ plane of nutrition is $y=$ $1.2756 x-0.3469, R^{2}=10.1 \%$. The slopes of these 2 curves are similar $(P=0.75)$.

this figure, the solid arrow and the dashed arrow indicate the average age at puberty for E- and R-heifers, respectively. As in Figure 3, heifers that did not reach puberty before harvest are represented by an open square (E-heifers) or dash (R-heifers). Heifers that reached puberty after harvest are indicated by an $\times(\mathrm{E}-$ heifers) or open triangle (R-heifers).

\section{DISCUSSION}

The reduction in prepubertal PAR DNA associated with elevated prepubertal nutrient intake demonstrated in this experiment is described in detail in the companion paper (Meyer et al., 2006). These data are consistent with most other data in the literature in which mammary development was assessed at a common BW but different ages (Sejrsen et al., 1982; Petitclerc et al., 1984; Capuco et al., 1995). Earlier research 


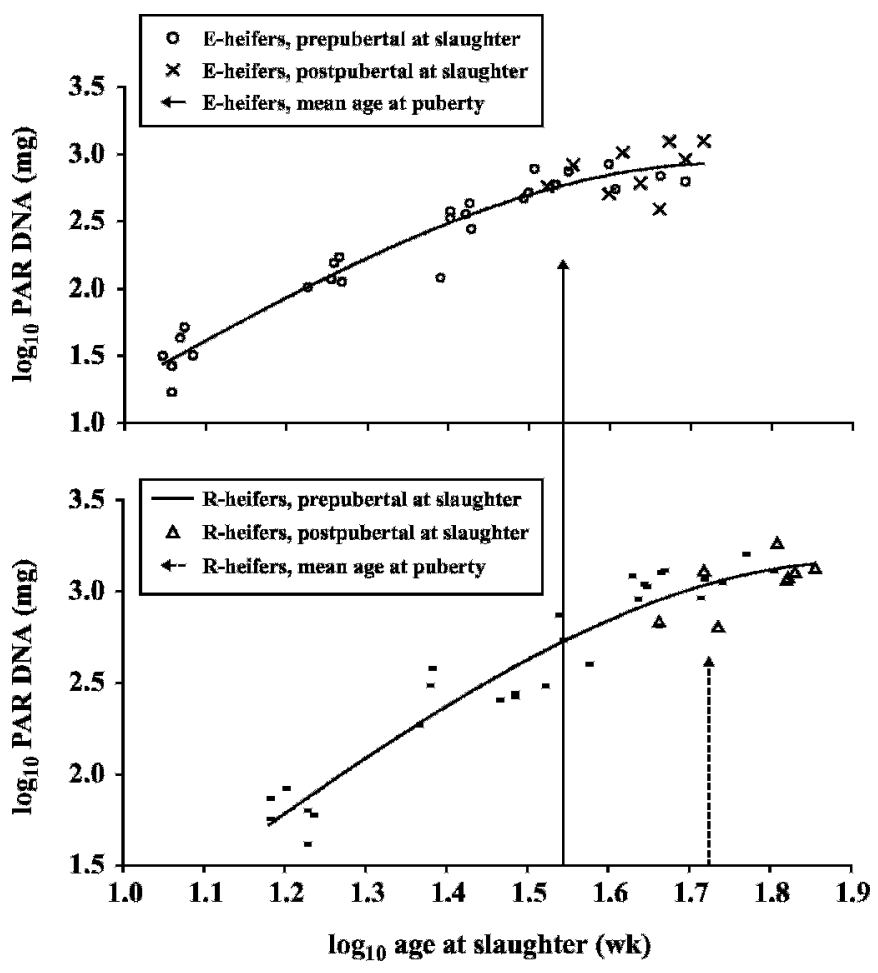

Figure 4. Prepubertal mammary parenchymal (PAR) development in heifers raised on an elevated $(\mathrm{E})$ or restricted $(\mathrm{R})$ plane of nutrition and harvested at $6 \mathrm{BW}$ between birth and $350 \mathrm{~kg}$. The top panel represents E-heifers. Specifically, those harvested before reaching puberty are represented by an open circle $(\bigcirc)$, whereas those that were postpubertal at harvest are represented by an $\times$. The bottom panel represents R-heifers. Specifically, those harvested before reaching puberty are represented by a dash $(-)$, whereas those that were postpubertal at harvest are represented by an open triangle $(\triangle)$. The average age at puberty is represented by solid and broken arrows for E- and R-heifers, respectively. Data are presented as $\log _{10}$ age at harvest (weeks) vs. $\log _{10}$ PAR DNA at harvest. The regression for Eheifers (top panel) is $y=-2.0313 x^{3}+6.1107 x^{2}-2.7893 x, \mathrm{R}^{2}=93.4 \%$, and the regression for R-heifers (bottom panel) is $y=-1.5643 x^{3}+$ $5.10292 x^{2}-2.384 x, \mathrm{R}^{2}=92.3 \%$.

has focused largely on establishing a direct link between elevated nutrient intake and impaired prepubertal epithelial cell proliferation, mammary growth, or both. However, the effects of elevated nutrient intake on mammary epithelial cell proliferation or PAR accretion have yet to be evaluated extensively. In the companion paper, we suggested that the length of time between birth and harvest is a primary determinant of total PAR DNA at harvest (Meyer et al., 2006). For this to be accepted, it must be demonstrated that elevated nutrient intake does not affect growth characteristics of the mammary PAR, including rates of PAR and epithelial cell growth. The data presented herein provide such evidence. Additionally, these data suggest that a heifer's physiological age (relative to the onset of puberty) is a major regulator of mammary development.
This paper demonstrates that the level of nutrient intake during the period of prepubertal mammary development has no significant effect on the development of the mammary PAR. Specifically, an elevated nutrient intake had no negative impact on BrdU incorporation by the mammary epithelial cells. Similar to this lack of effect on long-term epithelial cell proliferation, there was no difference in daily PAR DNA accretion rates among heifers on the 2 treatments. These data strongly suggest that growth of the developing mammary PAR (which accounts for both cell proliferation and apoptosis) is refractory to the level of nutrient intake, as suggested in the companion paper (Meyer et al., 2006). Last, we evaluated the effect of treatment on the dynamics of prepubertal allometric mammary growth. In agreement with the epithelial cell proliferation and PAR DNA accretion rates discussed above, the slopes of allometric (3.11 and 3.29 for R- and E-heifers, respectively) and isometric (1.44 and 1.28 for R- and E-heifers, respectively) mammary growth were similar between E- and R-heifers, as was the timing of exit from allometric mammary growth. Additionally, these slopes were remarkably similar to the allometric and isometric mammary growth rates (3.5 and 1.5, respectively) first reported by Sinha and Tucker (1969), indicating that the basic dynamics of prepubertal mammary development have remained constant despite $35 \mathrm{yr}$ of genetic selection for milk and other yield traits.

The data presented herein indicate that development of the mammary PAR is refractory to the level of nutrient intake and is largely unaffected by the physiological changes associated with increased nutrient intake, as experienced by the E-heifers but not the R-heifers. These physiological changes included increased plasma leptin concentrations, increased leptin transcript abundance in the PAR and mammary fat pad (S. R. Thorn, M. J. Meyer, M. E. Van Amburgh, and Y. R. Boisclair, unpublished data) and increased lipid deposition in the mammary fat pad (Meyer et al., 2006) and carcass (Meyer et al., 2004). Although intramammary leptin infusions have been reported to block epithelial cell proliferation in the prepubertal bovine mammary gland (Silva et al., 2003), the data presented herein suggest that physiological, diet-induced increases in plasma leptin appear to have no such antimitogenic activity. Additionally, although Silva et al. (2002) showed leptin to retard immortalized bovine mammary epithelial cells in vitro, Thorn et al. (2006) observed no such effect. Indeed, others have reported positive proliferative responses to leptin by both normal and neoplastic human mammary epithelial cell lines (Dieudonne et al., 2002; Hu et al., 2002).

A tendency for increased mammary epithelial cell proliferation was observed in E-heifers; however, this 
effect was most pronounced at $100 \mathrm{~kg}$ of BW, where BrdU incorporation was higher in E-heifers than in Rheifers. At this harvest weight, E-heifers were $1.0 \mathrm{mo}$ younger than their nutrient-restricted cohorts $(2.7 \mathrm{vs}$. 3.7 mo of age). Basal mammary epithelial cell proliferation declines at 2 to 5 mo of age (Ellis and Capuco, 2002); therefore, this age effect may be responsible for the $44 \%$ difference in proliferation we observed between E- and R-heifers at $100 \mathrm{~kg}$ of BW. Alternatively, increased epithelial cell proliferation may be the result of an elevated nutrient intake. In some model organisms, stem cells and their more differentiated daughter cells modulate their proliferation according to nutritional status (Drummond-Barbosa and Spradling, 2001). Therefore, one could speculate that the improved nutritional status of E-heifers during their early postnatal life may have brought about the increase in BrdU labeling by increasing the proliferation of mammary stem cells or their daughters, or both.

Irrespective of treatment, when heifers were between 250 and $300 \mathrm{~kg}$ of BW, the mammary gland received signals that elicited a 50\% reduction in the PAR DNA accretion rate (Figure 2), transitioning the mammary PAR out of allometric growth (Figure 3 ). This BW range also encompassed the average BW at puberty $(280 \mathrm{~kg})$, which was similar between E- and R-heifers. This effect on the mammary growth rate of entering the peripubescent period is apparent in Figures 2, 3, and 4. As shown in Figures 3 and 4, the inflection point at which the mammary growth curve plateaued occurred roughly at the average BW (Figure 3) and age (Figure 4) when heifers reached puberty. E-heifers reached puberty approximately $108 \mathrm{~d}$ before their cohorts on the restricted plane of nutrition, and this difference in age at puberty is apparent in Figure 4.

The observation that neither the allometric and isometric slopes nor the timing of exit from allometric growth were affected by treatment (Figures 2, 3, and 4) suggests that the mammary PAR receives developmental cues coordinated by the heifer's physiological age. Based on these data, exit of the mammary gland from allometric growth is associated with entry into the peripubescent period, but is not dependent on reaching puberty. Specifically, the PAR DNA mass of heifers that had not yet reached puberty but were harvested after the average age and BW at puberty fit the isometric PAR DNA growth curve of their pubertal cohorts (Figures 3 and 4). This is particularly evident in Figure 4. Therefore, the PAR of these prepubertal heifers [dashes (R) and open circles (E) in Figures 3 and 4] already appear to have exited allometric growth before they reached puberty. If exit from allometric mammary growth was dependent on estrus, the PAR DNA of prepubertal heifers would be expected to be greater than their age- or BW-matched pubertal cohorts. This effect was not observed (Figures 3 and 4).

\section{CONCLUSIONS}

We demonstrated that in vivo, basal proliferation of prepubertal bovine mammary epithelial cells is not negatively influenced by an elevated nutrient intake. In fact, a trend toward increased epithelial cell proliferation in response to elevated nutrient intake was observed in early life. In addition, the PAR DNA accretion rate (representing the sum of cell proliferation and apoptosis) and dynamics of prepubertal allometric PAR growth were essentially identical between heifers on an elevated or restricted level of nutrient intake. This lack of effect of an elevated nutrient intake on these parameters of prepuberal mammary development occurred in the wake of increased plasma leptin and altered nutrient partitioning to the mammary fat pad (Meyer et al., 2006) and carcass (Meyer et al., 2004). These data demonstrate that the developing mammary PAR is largely refractory to the subtle changes in homeorhetic signals involved in coordinating changes in nutrient partitioning that are brought about by an elevated nutrient intake. Therefore, the level of nutrient intake appears to have a minimal biologically significant influence on 1) mammary epithelial cell proliferation, 2) the rate of PAR DNA accretion, or 3) the total PAR DNA.

\section{ACKNOWLEDGMENTS}

The authors wish to thank Any Hummel for her assistance with quantitation of the BrdU labeling; R. A. Ehrhardt for plasma leptin analysis; and Denny Shaw, Bruce Berggren-Thomas, Joe McFadden, Matt Miller, Jenny Kelsey-Mills, and Erin Peterson for their help with animal care and tissue collection. We would also like to thank Jeff Tikofsky, Agway Feed and Nutrition (Syracuse, NY), and Mike Fowler, Land O'Lakes Animal Milk Products Company (St. Paul, MN) for their financial support of this experiment. This work was also partially funded by the Cornell University Agricultural Experiment Station and USDA-ARS. This research is a component of NC-1119: Management Systems to Improve the Economic and Environmental Sustainability of Dairy Enterprises.

\section{REFERENCES}

Block, S. S., J. M. Smith, R. A. Ehrhardt, M. C. Diaz, R. P. Rhoads, M. E. Van Amburgh, and Y. R. Boisclair. 2003. Nutritional and developmental regulation of plasma leptin in dairy cattle. J. Dairy Sci. 86:3206-3214.

Capuco, A. V., S. Ellis, D. L. Wood, R. M. Akers, and W. Garrett. 2002. Postnatal mammary ductal growth: Three-dimensional im- 
aging of cell proliferation, effects of estrogen treatment, and expression of steroid receptors in prepubertal calves. Tissue Cell $34: 143-154$

Capuco, A. V., J. J. Smith, D. R. Waldo, and C. E. Rexroad. 1995. Influence of prepubertal dietary regimen on mammary growth of Holstein heifers. J. Dairy Sci. 78:2709-2725.

Cowie, A. T., J. S. Tindal, and A. Yokoyama. 1966. The induction of mammary growth in the hypophysectomized goat. J. Endocrinol. 34:185-195.

Dieudonne, M. N., F. Machinal-Quelin, V. Serazin-Leroy, M. C. Leneveu, R. Pecquery, and Y. Giudicelli. 2002. Leptin mediates a proliferative response in human MCF7 breast cancer cells. Biochem. Biophys. Res. Commun. 293:622-628.

Drummond-Barbosa, D., and A. C. Spradling. 2001. Stem cells and their progeny respond to nutritional changes during Drosophila oogenesis. Dev. Biol. 231:265-278.

Ehrhardt, R. A., R. M. Slepetis, J. Sigeal-Willott, M. E. Van Amburgh, A. W. Bell, and Y. R. Boisclair. 2000. Development of a specific radioimmunoassay to measure physiological changes of circulating leptin in cattle and sheep. J. Endocrinol. 166:519-528.

Ellis, S., and A. V. Capuco. 2002. Cell proliferation in bovine mammary epithelium: Identification of the primary proliferative cell population. Tissue Cell 34:155-163.

Hu, X., S. C. Juneja, N. J. Maihle, and M. P. Cleary. 2002. LeptinA growth factor in normal and malignant breast cells and for normal mammary gland development. J. Natl. Cancer Inst. 94:1704-1711.

Labarca, C., and K. Paigen. 1980. A simple, rapid, and sensitive DNA assay procedure. Anal. Biochem. 102:344-352.

Meyer, M. J., A. V. Capuco, D. A. Ross, L. M. Lintault, and M. E. Van Amburgh. 2006. Developmental and nutritional regulation of the prepubertal heifer mammary gland: I. Parenchyma and fat pad mass and composition. J. Dairy Sci. 89:4289-4297.

Meyer, M. J., D. A. Ross, D. E. Shaw, and M. E. Van Amburgh. 2004. Components of growth in Holstein heifers reared from early life on two levels of energy intake. J. Dairy Sci. 87(Suppl. 1):210. (Abstr.)
Neter, J., W. Wasserman, and M. H. Kutner. 1990. Applied Linear Statistical Models: Regression, Analysis of Variance, and Experimental Design. Irwin, Boston, MA.

Petitclerc, D., L. T. Chapin, and H. A. Tucker. 1984. Carcass composition and mammary development responses to photoperiod and plane of nutrition in Holstein heifers. J. Anim. Sci. 58:913-919.

SAS Institute. 2000. Software Release 8.1. SAS Institute, Inc., Cary, NC.

Sejrsen, K. 1978. Mammary development and milk yield in relation to growth rate in dairy and dual-purpose heifers. Acta Agric. Scand. 28:41-46.

Sejrsen, K., J. T. Huber, and H. A. Tucker. 1983. Influence of amount fed on hormone concentrations and their relationship to mammary growth in heifers. J. Dairy Sci. 66:845-855.

Sejrsen, K., J. T. Huber, H. A. Tucker, and R. M. Akers. 1982. Influence of nutrition of mammary development in pre- and postpubertal heifers. J. Dairy Sci. 65:793-800.

Sejrsen, K., S. Purup, M. Vestergaard, M. S. Weber, and C. H. Knight. 1999. Growth hormone and mammary development. Domest. Anim. Endocrinol. 17:117-129.

Silva, L. F., J. S. Liesman, M. S. Nielsen Weber, and M. J. VandeHaar. 2003. Intramammary infusion of leptin decreases proliferation of mammary epithelial cells in prepubertal heifers. J. Dairy Sci. 82(Suppl. 1):166. (Abstr.)

Silva, L. F., M. J. VandeHaar, M. S. Weber Nielsen, and G. W. Smith 2002. Evidence for a local effect of leptin in bovine mammary gland. J. Dairy Sci. 85:3277-3286.

Sinha, Y. N., and H. A. Tucker. 1969. Mammary development and pituitary prolactin level of heifers from birth through puberty and during the estrous cycle. J. Dairy Sci. 52:507-512.

Thorn, S. R., S. Purup, W. S. Cohick, M. Vestergaard, K. Sejrsen, and Y. R. Boisclair. 2006. Leptin does not act directly on mammary epithelial cells in prepubertal dairy heifers. J. Dairy Sci. 89:1467-1477. 